\title{
A Functional Study of Transforming Growth Factor-Beta from the Gonad of Pacific Oyster Crassostrea gigas
}

\author{
Charlotte Corporeau ${ }^{\mathrm{a}, \mathrm{d},{ }^{*},}$, Agnès Groisillier ${ }^{\mathrm{b}}$, Alexandra Jeudy ${ }^{\mathrm{b}}$, Tristan Barbeyron $^{\mathrm{b}}$, Elodie Fleury ${ }^{\mathrm{a}}$, \\ Caroline Fabioux ${ }^{\mathrm{c}}$, Mirjam Czjzek ${ }^{\mathrm{b}}$ and Arnaud Huvet $^{\mathrm{a}}$
}

\footnotetext{
a UMR 100 Ifremer-Université de Caen, PE2M, 29280 Plouzané, France.

b CNRS-UPMC Univ Paris 6, UMR 7139 Végétaux marins et Biomolécules, LIA DIAMS, Station Biologique, 29682, Roscoff, France.

' UMR CNRS 6539, LEMAR, Université de Bretagne Occidentale, IUEM, 29280 Plouzané, France.

d Département de Physiologie Fonctionnelle des Organismes Marins. Ifremer. Technopôle Brest-Iroise. BP70. 29280 Plouzané, France.
}

*: Corresponding author : Charlotte Corporeau, email address : charlotte.corporeau@ifremer.fr

\begin{abstract}
:
The transforming growth factor (TGF)- $\beta$ superfamily is a group of important growth factors involved in multiple processes such as differentiation, cell proliferation, apoptosis and cellular growth. In the Pacific oyster Crassostrea gigas, the oyster gonadal (og) TGF- $\beta$ gene was recently characterized through genome-wide expression profiling of oyster lines selected to be resistant or susceptible to summer mortality. Og TGF- $\beta$ appeared specifically expressed in the gonad to reach a maximum when gonads are fully mature, which singularly contrasts with the pleiotropic roles commonly ascribed to most TGF- $\beta$ family members. The function of og TGF- $\beta$ protein in oysters is unknown, and defining its role remains challenging. In this study, we develop a rapid bacterial production system to obtain recombinant og TGF- $\beta$ protein, and we demonstrate that og TGF- $\beta$ is processed by furin to a mature form of the protein. This mature form can be detected in vivo in the gonad. Functional inhibition of mature og TGF- $\beta$ in the gonad was conducted by inactivation of the protein using injection of antibodies. We show that inhibition of og TGF- $\beta$ function tends to reduce gonadic area. We conclude that mature og TGF- $\beta$ probably functions as an activator of germ cells development in oyster.
\end{abstract}

Keywords : Transforming growth factor- $\beta$-Bacterial expression-In vivo antibody inhibition Reproduction - Crassostrea gigas - Marine bivalve 


\section{Introduction}

The Pacific oyster Crassostrea gigas is prone to a complex summer mortality phenomenon, a major concern among oyster farmers (Samain et al., 2007; Samain \& McCombie, 2008). Mortality results from interactions between environmental factors, pathogens and oyster physiological status (Samain and McCombie, 2008). Indeed, at the physiological level, reproduction in oysters is linked with summer mortality, and ripeness (the pre-spawning stage when oyster gonads are fully developed) appeared to be a critical period of vulnerability, mainly for oysters displaying high reproductive effort (Samain et al., 2007; Huvet et al., 2010). A recently conducted genome-wide expression profiling of oyster lines selected to be resistant (R) or susceptible (S) to summer mortality highlights reproduction and reproductive allocation as one of the principal pathways that play a role in resistance to summer mortality (Fleury et al., 2010). From the 34 ESTs reported to operate differentially between R and $S$ lines, one EST corresponded to the gene oyster-gonadal Transforming Growth Factor- $\beta$ (og TGF- $\beta$ ), a new TGF- $\beta$ superfamily member (Fleury et al., 2008) Based on its tissue-specific mRNA expression in the germinal cells of both male and female gonads, og TGF- $\beta$ was supposed to play a role in germinal cell proliferation and/or maturation (Fleury et al., 2008). In contrast, other members of TGF- $\beta$ superfamily already identified in this model were ubiquitously expressed in all adult tissues and played a role in immunity or larval development (Herpin et al., 2004; Lelong et al., 2000, 2007). However, until now, no information had been obtained neither on the structure of og TGF- $\beta$ protein nor on its function in oysters.

The TGF- $\beta$ superfamily is a functionally diverse group of cytokines that regulate differentiation, proliferation, cellular growth, apoptosis or gene expression of several types of cell (Ten Dijke et al., 2000; Patterson and Padgett, 2000). A common feature of most TGF- $\beta$ members is the presence of seven conserved cysteine residues, six of which form a typical cysteine knot structure, and one that forms the inter-subunit disulfide bond responsible for the covalent linkage of two subunits of the dimeric, biologically active ligand (Moore and Shimasaki, 2005). TGF- $\beta$ superfamily members all possessed these conserved cysteine residues, but molecules are known by multiple names due to the circumstances of their discovery (Itman et al., 2006). Members of this superfamily have been further classified into several subfamilies: the TGF- $\beta$ subfamily sensu stricto, an extensive bone morphogenetic protein (BMP) subfamily, the growth and differentiation factor (GDF) subfamily, the activin/inhibin subfamily, as well as several divergent factors (Knight and Glister, 2006). In vertebrates, TGF- $\beta$ superfamily members are secreted by cells and interact with both type II and type I serine/threonine kinase receptors to transduce their signals through a signalling pathway involving specific Smad nuclear effectors that modulate gene expression and cellular properties (Ten Dijke et al., 2000; Massague and Wotton, 2000). Some members of the TGF- $\beta$ superfamily exhibit specific roles in reproductive tissues by regulating the function of the ovary or testis (Josso and Di Clemente, 1999; Ingman and Robertson, 2002; Knight and Glister, 2006; Schulz et al., 2009). In mammals, TGF- $\beta$ members act as paracrine factors, playing multiple roles in testis development (for a review, see Itman et al., 2006) or in ovarian functions such as stimulation of follicle development and maturation, steroid hormone production and gonadotropin sensitivity (Shimasaki et al., 2004; Knight and Glister, 2006). In lower vertebrates, some TGF- $\beta$ members were reported to stimulate primordial germ cell and spermatogonial proliferation in rainbow trout (Sawatari et al., 2007) or to inhibit oocyte maturation in zebrafish (Kohli et al., 2003, 2005).

In the Pacific oyster Crassostrea gigas, og TGF- $\beta$ mRNA is exclusively located in the somatic cells surrounding germinal cells in both male and female gonads (Fleury et al., 2008). Relative quantity of og TGF- $\beta$ transcripts was seen to increase continuously during the development of the gonadal tubules and to achieve a maximal level when germ cells are fully mature (Fleury et al., 2008). In the present study, we develop a bacterial expression system 
to produce the recombinant protein og TGF- $\beta$ to gain information about its structure and function in the gonad of $C$. gigas. In vivo functional inactivation of mature og TGF- $\beta$ using antibody injection was used to study the function of og TGF- $\beta$ in the gonad of oysters.

\section{Materials and methods}

\subsection{Bacterial expression of recombinant pro-og TGF- $\beta$}

To produce pro-og TGF- $\beta$ protein in bacteria, the pro-og TGF- $\beta$ cDNA was inserted into an expression plasmid pGEX4 (GE Healthcare Life Science, Pittsburgh, PA, USA). This vector adds a GST-tag of $25 \mathrm{kDa}$ at the $\mathrm{N}$-terminus part of the recombinant protein that is fundamental for its successive detection and purification. The procedure for bacterial expression was done as described by Groisillier et al. (2010). Briefly, the plasmid carrying an inducible T7 promoter was transformed into E. coli host strain BL21 (Novagen, Gibbstown, $\mathrm{NJ}$, USA) Then, in small-scale culture, the bacterial pellet was resuspended in $500 \mu \mathrm{l}$ lysis buffer $(20 \mathrm{mM}$ Tris- $\mathrm{HCl}$ pH 8.0, $500 \mathrm{mM} \mathrm{NaCl}, 1 \mathrm{mM}$ EDTA, $0.1 \%$ Triton X100, DNase 1 $\mathrm{mg} / \mathrm{ml}$, lysosyme $1 \mathrm{mg} / \mathrm{ml})$. Soluble and insoluble fractions were separated by centrifugation (12 $000 \mathrm{~g}, 20 \mathrm{~min}, 4^{\circ} \mathrm{C}$ ). The insoluble pellet was resuspended in $200 \mu \mathrm{l}$ lysis buffer supplemented with $6 \mathrm{M}$ urea, and the soluble fraction was purified on Microspin GST purification columns (GE Healthcare Life Science, Pittsburgh, PA, USA) according to manufacturer's instructions. Samples from soluble and insoluble fractions were separated by $12 \%$ sodium dodecyl-sulfate polyacrylamide gel electrophoresis (SDS-PAGE). In large-scale culture, the bacterial pellet was resuspended in PBS buffer $(1.4 \mathrm{M} \mathrm{NaCl}, 27 \mathrm{mM} \mathrm{KCl}, 101$ $\left.\mathrm{mM} \mathrm{Na} \mathrm{HPO}_{4}, 18 \mathrm{mM} \mathrm{KH} \mathrm{PO}_{4} ; \mathrm{pH} 7.3\right)$ containing $0.1 \mathrm{mg} / \mathrm{ml}$ of DNase and antiprotease cocktail (Complete EDTA-free tablets, Roche Applied Science, USA) and disrupted using a French press before centrifugation $\left(12000 \mathrm{~g}, 90 \mathrm{~min}, 4^{\circ} \mathrm{C}\right)$. The resulting supernatant was applied onto a Glutathione Sepharose ${ }^{\mathrm{TM}}$ High Performance column (GE Healthcare Life Science, Pittsburgh, PA, USA) and the bound recombinant proteins were eluted with elution buffer (50 mM Tris- $\mathrm{HCl}, 10 \mathrm{mM}$ reduced glutathione, $\mathrm{pH}$ 8). Results were analysed by $12 \%$ SDS-PAGE electrophoresis. Protein eluted was then partially purified and concentrated using CENTRICON ${ }^{\circledR}$ centrifugal filters (Millipore, Billerica, MA, USA) according to manufacturer's instructions and protein concentration was estimated using a NanoDrop ND-1000 Spectrophotometer at $280 \mathrm{~nm}$ (Thermo Fisher Scientific Inc., Waltham, MA, USA).

\subsection{In vitro thrombin and furin digestion}

For thrombin digestion, $5 \mu \mathrm{g}$ of eluted recombinant pro-og TGF- $\beta$ was added to one unit of thrombin (Affinity Bioreagents, New England Biolabs, MA, USA) in PBS buffer. For furin digestion, $5 \mu \mathrm{g}$ of eluted recombinant pro-og TGF- $\beta$ was added to one unit of furin (Affinity Bioreagents, New England Biolabs, MA, USA), either in the manufacturer's recommended buffer (100 mM HEPES pH 7.5, 0.5\% triton X100, 1 mM CaCl, $1 \mathrm{mM}$ 2-mercaptoethanol) or a previously published furin buffer $(50 \mathrm{mM}$ Tris- $\mathrm{HCl} \mathrm{pH} 7.5,150 \mathrm{mM} \mathrm{NaCl}, 5 \mathrm{mM} \mathrm{CaCl}, 1$ $\mathrm{mM}$ 2-mercaptoethanol; Leighton and Kadler, 2003). Furin digestion was processed at $20{ }^{\circ} \mathrm{C}$ or $37{ }^{\circ} \mathrm{C}$ from $5 \mathrm{~min}$ to 24 hours under rotative agitation. The digestion products were analysed by $12 \%$ SDS-PAGE and detected by staining with Coomassie brilliant blue.

\subsection{Tissue protein extraction}

Gonads were isolated from a pool of 20 male or 20 female oysters of two-years aged grown in a hatchery under controlled conditions during five weeks and sampled at mature reproductive stage (stage 3) according to Fabioux et al. (2004). Tissues collected were immediately frozen and powdered in liquid nitrogen. Homogenized tissues $(1 \mathrm{~g})$ were solubilized in ice-cold lysis buffer $(150 \mathrm{mM} \mathrm{NaCl}, 10 \mathrm{mM}$ Tris, 1 mM EDTA, 1 mM EGTA, $1 \%$ Triton X-100, $0.5 \%$ Igepal, $2 \mathrm{mM}$ PMSF, $10 \mu \mathrm{g} / \mathrm{ml}$ leupeptin, $10 \mu \mathrm{g} / \mathrm{ml}$ aprotinin, $100 \mathrm{mM}$ 
sodium fluoride, $10 \mathrm{nM}$ sodium pyrophosphate, and $2 \mathrm{mM}$ sodium orthovanadate; $\mathrm{pH} 7.4$ ) and proteins were extracted as described by Le Foll et al. (2007).

\subsection{Western-blot procedures}

Protein lysates were quantified using DC protein assay (Bio-rad, Hercules, CA, USA) and diluted at the same concentration in ice-cold lysis buffer. An equal amount of $20 \mu \mathrm{g}$ of total protein extracts from gonad in each sample was denatured in Laemmli buffer before loading onto $15 \%$ SDS-PAGE. One $\mu \mathrm{g}$ of the furin-digestion products of recombinant pro-og TGF- $\beta$ was also denatured by Laemmli buffer and loaded in parallel with protein extracts from gonad. Proteins were then transferred onto a PVDF membrane (Bio-Rad, Hercules, CA, USA). Immunoblotting was performed using a commercially available heterologous panspecific anti-TGF- $\beta$ polyclonal antibody (AB-100-NA, RnD Systems, Minneapolis, USA; dilution $1: 1000)$ as primary antibody and alkalin-phosphatase anti-rabbit lgG as secondary antibody (Bio-rad, Hercules, CA, USA; dilution 1/5000). Bands were revealed with a Immunstar AP detection kit (Bio-rad, Hercules, CA, USA) and band intensities were quantified by optical densitometry (Gel Doc XR scanning software, Biorad, Hercules, CA, USA). Dehybridization was done at room temperature for 1 hour by incubating the membrane in dehybridization buffer (100 mM glycine, $100 \mathrm{mM} \mathrm{NaCl}, \mathrm{pH}$ 3.2) before immunodetection using anti-histone H3 antibody (\#9715; Cell Signaling Technology, Danvers, MA, USA; dilution 1:5000) to verify that there was identical amount of total protein extracts from gonad loaded in each well, as described in Fabioux et al. (2009).

\subsection{In silico analyses}

Using InterProScan (Zdobnov and Apweiler, 2001), a consensus cleavage site, RFKR, was predicted in the C-terminal region of the protein of 307 amino acids encoded by the gene og TGF- $\beta$. Protein modeling of C-terminal mature og TGF- $\beta$ was performed using SWISSMODEL (http://swissmodel.expasy.org), then a diagram was produced using Swiss-Pdb Viewer (http://www.expasy.org/spdbv/; Arnold et al., 2006).

\subsection{In vivo antibody injection and semi-quantitative histology}

Twenty oysters of two-years aged were obtained from Marennes-Oléron (France) cultured stocks, and transferred to the Ifremer Laboratory in Argenton (France). They were acclimated for 1 week and maintained in raceways during eight days (TO to T8) in conditions allowing optimal germ cell maturation (Fabioux et al., 2005). Oysters were injected at T0, T3 (3 days) and T7 (7 days) with a solution containing pan-specific anti-TGF- $\beta$ polyclonal antibody (AB100-NA, RnD Systems, Minneapolis, USA) diluted in PBS $(n=10)$ or with the same volume of PBS $(n=10)$. Direct injection in the gonad was demonstrated to be an efficient method in oyster (Fabioux et al., 2009). We therefore administrated the antibody by reitered injection directly in the gonad at $1.5 \mathrm{mg}$ of antibody per $\mathrm{kg}$ for each injection, a dose used in vertebrate models by intraperitoneal injection (Ma et al., 2004). At T8, antibody-injected and control oysters were sampled, their gonads were immediately dissected and a transverse section of all the gonadic area was taken for histological examination of gonadic development according to Fabioux et al (2009). Only two different stages were observed in the present study, (3) ripe, (4) partially spent, according to the scale of Steele and Mulcahy (1999). Percentage areas of gonadic tubules, conjunctive tissue and digestive gland were then determined on each histological section. Slides were scanned with a digital scanner (HP scanjet 7400c) and the images saved in *.TIFF format. Tissue areas were then measured using image analysis software (Imaq Vision Builder, National Instruments Corp.). Gonad area percentage was estimated as pixel number, from gonad / pixel number on total sections, as described in Fabioux et al. (2005). Comparisons of the gonad area between conditions (antibody injection versus control) was performed by Student's t-test using STATGRAPHICS software after angular transformation of the percentages of gonad area. 


\section{Results}

\subsection{Production of recombinant pro-og TGF $\beta$}

To obtain the recombinant pro-og TGF- $\beta$ protein, we cloned the pro-og TGF- $\beta$ cDNA (Genbank accession number: EF563990; Fleury et al., 2008) encoding the pro-og- TGF- $\beta$ lacking its signal peptide (Fig. $1 \mathrm{~A}$ ) into the pGEX4-T1 expression vector. The GST-tagged pro-og TGF- $\beta$ recombinant protein generated by this cloning strategy has a predicted molecular weight of $58 \mathrm{kDa}$ (Fig. $1 \mathrm{~B}$ ). Thrombin (Fig. $1 \mathrm{~B}$, white arrow) liberates the $25 \mathrm{kDa}$ fGST-tag and is expected to produce a $33 \mathrm{kDa}$ fragment corresponding to pro-og TGF. If cleavage by furin (Fig. $1 \mathrm{~B}$, black arrow) is effective, it is expected to produce two fragments, one of $13.6 \mathrm{kDa}$ corresponding to mature og TGF- $\beta$ and one of $44.4 \mathrm{kDa}$ corresponding to GST-tagged pro-fragment .

After bacterial production, recombinant proteins were rapidly purified on Microspin GST purification columns and analysed by $12 \%$ SDS-PAGE. By coloration, one major band was revealed at the molecular weight of approximately $58 \mathrm{kDa}$ (Fig. $2 \mathrm{~A}$, black arrowhead). This size is in close agreement with the molecular weight predicted from the amino-acid sequence of recombinant GST-tagged pro-og TGF- $\beta$ inferred from the cDNA sequence in the expression vector. Since this band was also revealed by immunodetection using anti-GST antibodies (data not shown), our production protocol was validated and we carried-out largescale production of this protein. As shown in Fig. $2 \mathrm{~B}$, the synthesized 58-kDa protein was obtained in the soluble fraction of proteins although it was not detectable in insoluble proteins from bacteria pellet.. After HPLC purification, the synthesized GST-tagged pro-og TGF- $\beta$ appeared as a $58 \mathrm{kDa}$ band (Fig. $2 \mathrm{C}$ ) and was recognized by anti-GST antibody after immunodetection on western-blot (data not shown). The other upper band at $65 \mathrm{kDa}$ (Fig. 2 C) was not recognized using GST antibody and was considered as a contaminant of the partially purified recombinant pro-og TGF- $\beta$. Several lower bands appeared at less than 30 $\mathrm{kDa}$ and were also considered as contaminants. Fractions eluted from HPLC containing GST-tagged pro-og TGF- $\beta$ were then pooled, and recombinant protein was concentrated using centrifugal filters to obtain GST-tagged pro-og TGF- $\beta$ at a concentration of approximately $0.1 \mathrm{mg} / \mathrm{ml}$.

\subsection{Cleavage of recombinant pro-og TGF- $\beta$ by thrombin and furin}

Although contamination of eluted GST-tagged pro-og TGF- $\beta$ recombinant protein was evident, it was used for in vitro thrombin or furin digestion assays. A representative example of $12 \%$ SDS-PAGE analysis of digestion products is shown in Fig. 3. The time course of digestion was examined by sampling $5 \mu \mathrm{l}$ of digest products at $1 \mathrm{~min}, 30 \mathrm{~min}, 1$ hour, 2 hours, 3 hours and 24 hours after enzyme addition at time 0 . We show that the 58-kDa-band (Fig. $3 \mathrm{~A}$, black arrowhead) disappeared rapidly after incubation with thrombin, confirming that this band contained a GST-tag. Indeed, thrombin digestion yielded two fragments, one corresponding to $33 \mathrm{kDa}$ (Fig. $3 \mathrm{~A}$, grey arrowhead), the size of pro-og TGF- $\beta$ lacking its GST-tag, and the other to $25 \mathrm{kDa}$ (Fig. $3 \mathrm{~A}$, white arrowhead), the size of the GST-tag alone. These results demonstrate the integrity of recombinant GST-tagged pro-og TGF- $\beta$ at a band of $58 \mathrm{kDa}$ and illustrate the efficiency of its GST-digestion by thrombin. Using furin, the 58kDa-band (Fig. $3 \mathrm{~B}$, black arrowhead) corresponding to the recombinant GST-tagged pro-og TGF- $\beta$ was partially digested. Two buffers and temperatures were tested and digestion was only partial but more effective over 24 hours after addition of the enzyme. The 58-kDaprotein was cleaved to yield a $44.4 \mathrm{kDa}$ protein (Fig. $3 \mathrm{~B}$, grey arrowhead) corresponding to the expected size of GST-tagged-pro-fragment liberated from the mature og TGF- $\beta$. The resulting mature og TGF- $\beta$ migrating at the size of $13.6 \mathrm{kDa}$ was not resolved on this $12 \%$ SDS-PAGE. 


\subsection{Detection of mature og TGF- $\beta$ in the oyster gonad}

Using immunodetection on western-blot, we demonstrated that the commercially available heterologous pan-specific anti-TGF- $\beta$ polyclonal antibody could recognize the recombinant mature og TGF- $\beta$ of $13.6 \mathrm{kDa}$ loaded onto a 15\% SDS-PAGE gel. Using the same method, we analysed total protein extracts from gonad of male and female oysters sampled at the reproductive stage where gonads are fully mature (stage 3 ). Proteins were electrophoresed then transferred onto a membrane for immunodetection using pan-specific anti-TGF- $\beta$ polyclonal antibody or a histone $\mathrm{H} 3$ antibody to control that equal amounts of gonad proteins had been loaded into the gel (data not shown). As shown in Fig. 4, the pan-specific anti-TGF$\beta$ antibody recognizes a band at $13.6 \mathrm{kDa}$ corresponding to mature og TGF- $\beta$ detected both in male and female gonad protein extracts (Fig. 4, M, F).

\subsection{D structural prediction of mature og TGF- $\beta$}

We analyzed the three dimensional structure prediction of the C-terminal mature og TGF- $\beta$ of $13.6 \mathrm{kDa}$ liberated by furin, to gain information about its structureby comparison with other biologically active TGF- $\beta$-related proteins. In silico analysis showed that the predicted structure of mature og TGF- $\beta$ is built as a typical TGF- $\beta$ superfamily member, and shares secondary-structure elements displaying a conserved $\alpha$-helix and several $\beta$-strands that delineate two fingers (Fig. 5). By screening the available crystallographic structures of TGF- $\beta$ members within the PDB protein data bank, we found that oyster mature og TGF- $\beta$ three dimensional structure shares the highest identity score (23\%; E-value of $11^{-35}$ ) with the crystal structure of human bone morphogenetic protein BMP-2 (Fig. 5; structure ID: 3bmp; (Scheufler et al, 1999) that belongs to TGF- $\beta$ superfamily. However, it does not contain the additional small secondary structure element ( $\alpha$-helix) in the loop region that is specific to the BMP sub-group (Fig. 5, asterisk), strenghthening its assignation as a member of TGF- $\beta$ subgroup, as previously described by Fleury et al. (2008).

\subsection{In vivo antibody injection in the gonad}

To neutralize the function of mature og-TGF $\beta$, we injected the pan-specific anti-TGF- $\beta$ antibody in vivo in the gonad of oysters maintained in food and temperature conditions known to stimulate oyster gonadic development. The injection was done three times during two weeks directly in the gonad to ensure a chronic neutralization. This antibody was chosen for its ability to neutralize the biological activity of several TGF- $\beta$ in different species. At the end of the treatment, we performed histological analysis of gonadic tissue sections. From the 20 oysters conditioned, 19 were alive at the end of the experiment and 17 were analyzed for the gonadic area. Two oysters in the control condition were not considered in the present analysis due to figures of partial spawning observed on histological slides. Gonadic tissue surface percentages varied from 16.9 to $33.5 \%$ for the oysters injected with the pan-specific anti-TGF- $\beta$ polyclonal antibody, and from 26.8 to $51.1 \%$ for the control oysters injected with PBS (Fig. 6). The data showed that oysters injected with antibody had a significant $(P=0.003)$ lower mean gonad surface area $(25.4 \pm 5.8 \%)$ than control oysters $(37.0 \pm 7.9 \%)$ with an estimated mean difference of $11.6 \%$. 


\section{Discussion}

Using the recombinant pro-og TGF- $\beta$, we demonstrated that furin (Leighton and Kadler, 2003)liberates a mature og TGF- $\beta$ protein of $13.6 \mathrm{kDa}$ as in vertebrates. Indeed, members of TGF- $\beta$ superfamily are produced as inactive pro-protein and activation is linked to the elimination of the pro-domain by furin (Blanchette et al., 1997; Leighton and Kadler, 2003). Furin convertase liberates the biologically active TGF- $\beta$ mature protein that can be recognized by specific transmembrane receptors to stimulate its intracellular signalling pathway (Cui et al., 1998; Chang et al., 2002). However, the cleavage of the pro-domain is necessary but not always associated with receptor signal transduction since mature TGF- $\beta$ liberated from its pro-domain can also bind directly to the cell surface to stimulate its internalisation and degradation when it is not associated with its receptor (Lyon et al., 1997; Rider, 2006).

In oyster, we were particularly interested in examining three-dimensional structure of mature og TGF- $\beta$, since it contains only six cysteine residues including the fourth, but lacking the seventh characteristic residue (Fleury et al., 2008). By in silico analyses (Guex and Peitsch, 1997) we demonstrated that absence of the seventh cysteine does not interfere with the adoption of a typical TGF- $\beta$ three dimensional conformation. Our data also demonstrate that mature og TGF- $\beta$ is a protein that might be able to dimerize to exert its function in oystersince the common structure of oyster og TGF- $\beta$ and human BMP-2 is the cysteine-knot motif and two finger-like double-stranded beta-sheets that are typical for TGF- $\beta$ superfamily members known to dimerize (Scheufler et al, 1999; Herpin et al., 2004). Absence of the seventh cysteine was already reported for a member of TGF- $\beta$ superfamily isolated from the gonad of rainbow trout, named Gonadal Soma-Derived growth Factor GSDF (Sawatari et al., 2007). These authors supposed that GSDF lacking this cysteine would not be able to form a dimer, and could thus function as a monomer, but these authors did not present any structure modeling or any evidence for monomeric or dimeric structure of the native GSDF.

Apart from a commonly pleiotropic role in several physiological processes, such as cellular proliferation, differentiation, matrix production and apoptosis (Massague et al., 2000; Ten Dijke et al., 2000), few components of the TGF- $\beta$ system exhibit specific roles in reproductive tissues. However, a diverse range of activities for each of the TGF- $\beta$ members in many aspects of reproduction has been suggested (Ingman and Robertson, 2002; Moore et al., 2004; Moore and Shimasaki, 2005; Knight and Glister, 2006; Mendez et al., 2006). In this study, we showed that the mature form of og TGF- $\beta$ was recognized by the pan-specific antiTGF- $\beta$ antibody. This antibody was produced to be effective in a large range of species, from human to amphibian, and is directed against the C-terminal mature part of TGF- $\beta$ (Ma et al., 2004; Hernandez-Pando et al., 2006). Because of the lack of proteomic tools to study protein of marine organisms, the choice of such an antibody was made on the basis of its recognition of mature TGF- $\beta$ protein in multiple species. We compared the antigen of other commercially available anti-TGF- $\beta$ antibodies with our amino-acid sequence and found that they did not match sufficiently to be effective in our model. The mature og TGF- $\beta$ might thus be the in vivo functional factor as described for vertebrate homologues (Blanchette et al., 1997).

Using pan-specific anti-TGF- $\beta$ antibody, we performed an in vivo antibody neutralization by injection directly in the gonad. Such in vivo immuno-inhibition studies are often used in vertebrate models (Sharma et al., 1996; Omer and Riley, 1998; Ma et al., 2004; Pinheiro et al., 2005) and the pan-specific anti-TGF- $\beta$ antibody neutralizes the biological activity of TGF$\beta$ in many species (Biswas et al., 2006) to demonstrate its role in several physiological processes (Dumont and Arteaga, 2003; Subramanian et al., 2004; Pinheiro et al., 2005; Biswas et al., 2006; Hernandez-Pando et al., 2006). The same method was used to analyse the role of TGF- $\beta$ in proliferation of ovarian somatic cells or differentiation of spermatocytes in 
vitro (Gilchrist et al., 2004; Clelland et al., 2006; Mendez et al., 2006). In any case, such in vivo functional study offer an advantageous method for defining the role of a given protein in oyster. Improvement of this functional method must be done (dose and time-dependent effects, number and timing of injections, duration before sampling) with the aim of forcing the phenotype modifications between individuals, since a high variability of response was always observed in functional studies in oysters (Fabioux et al., 2009). Here, the entire og TGF- $\beta$ was produced and the mature form was partially purified after in vitro digestion that was not very potent. Using the protocol detailed in this study, we can now emphasize the production of a recombinant mature og TGF- $\beta$ that will be very helpful to obtain a specific antibody and better study the TGF- $\beta$ expression in oyster.

Here we demonstrated that in the presence of neutralizing antibody, oysters presented a significantly reduced gonad area meaning a reduced number and/or size of gametes produced. Indeed, the percentage surface occupied by the gonad is directly linked to the number and/or size of gametes produced and is therefore representative of the reproductive effort of oysters (Royer et al., 2008; Huvet et al., 2010). A positive effect of og TGF- $\beta$ is therefore suggested in germ cell development of oysters even though a negative effect was previously suggested for og TGF- $\beta$ based on its over-expression in families displaying a reduced reproductive effort (Fleury et al., 2008). In any case, such in vivo functional study offer an advantageous method for defining the potent role of TGF- $\beta$ in germ cell development in oyster. In vertebrates, some TGF- $\beta$ members are potent stimulators of folliculogenesis and ovulation quota (Vitt et al., 2001; Knight and Glister, 2006) while other TGF- $\beta$ members exert an inhibitory effect on gonad development (Moore et al., 2004). Some TGF- $\beta$ superfamily members expressed in ovary and testis play a role as mitogens during folliculogenesis, stimulating proliferation of granulosa cells (Otsuka et al., 2001; Shimasaki et al., 2004). In contrast, in TGF- $\beta$ 2-null-mutant mouse model, the number of germ cells increased in ovary (Memon et al., 2008). In lower vertebrates such as fish, some TGF- $\beta$ members have an inhibitory effect on oocyte maturation in zebrafish (Kohli et al., 2003, 2005; Ge, 2005; Clelland et al., 2006) and steroid production in goldfish (Calp et al., 2003) while others can stimulate proliferation of primordial germ cells and spermatogonia in trout (Sawatari et al., 2007).

In conclusion, our work suggests that mature og TGF- $\beta$ in the gonad acts as a stimulator of germ cell development in oyster. We clearly do not demonstrate whether mature og TGF- $\beta$ is in monomeric or multimeric form to exert its function in vivo but we show that og TGF- $\beta$ three dimensional structure might be compatible with dimerization. To gain insight into the molecular evolution of the structure-function of TGF- $\beta$ superfamily, our future projects aim to obtain high-resolution detailed structure on the functional mature og TGF- $\beta$ by determining its $X$-ray crystal structure. This work constitutes a major starting point to better understand an invertebrate TGF- $\beta$ function in reproduction events in oysters.

\section{Acknowlegments}

The present research project was supported by "Europole Mer" (www.europolemer.eu; project "OxyGenes") and by ANR (project "Gametogenes"). The authors are grateful for the financial support from the 'Marine Genomics Europe' network of excellence (European Commission contract \# GOCE-CT-2004-505403). E. Fleury was funded by Ifremer and a Région Basse-Normandie doctoral grant. We thank all the staff of the Argenton experimental hatchery for conditioning oysters. The authors are indebted to J.Y. Daniel, V. Quilien and C. Quéré for advice and technical assistance. We thank J. Moal for her comments on the manuscript and $\mathrm{H}$. McCombie for editing the English language. 


\section{References}

Arnold, K., Bordoli, L., Kopp, J., and Schwede, T. (2006). The SWISS-MODEL Workspace: A web-based environment for protein structure homology modelling. Bioinformatics 22:195201.

Biswas, S., Criswell, T.L., Wang, S.E., and Arteaga, C.L. (2006). Inhibition of transforming growth factor-beta signaling in human cancer: targeting a tumor suppressor network as a therapeutic strategy. Clin Cancer Res 12:4142-4146.

Blanchette, F., Day, R., Dong, W., Laprise, M.H., and Dubois, C.M. (1997). TGF- 1 regulates gene expression of its own converting enzyme furin. J Clin Invest 99:1974-1983.

Calp, M.K., Matsumoto, J.A., and Van der Kraak, G. (2003). Activin and transforming growth factor- $\beta$ as local regulators of ovarian steroidogenesis in the goldfish. Gen Comp Endocrinol 132:142-150.

Chang, H., Brown, C.W., Matzuk, M.M. (2002). Genetic analysis of the mammalian transforming growth factor- $\beta$ superfamily. Endocr Rev 23:787-823.

Clelland, E., Kohli, G., Campbell, R.K., Sharma, S., Shimasaki, S., and Peng, C. (2006). Bone-morphogenetic protein-15 in the zebrafish ovary: complementary deoxyribonucleic acid cloning, genomic organization, tissue distribution, and role in oocyte maturation. Endocrinology 147(1): 201-209.

Cui, Y., jean, F., Thomas, G., and Christian, J.L. (1998). BMP-4 is proteolytically activated by furin and/or PC6 during vertebrate embryonic development. EMBO J 17:4735-4743.

Dumont, N., and Arteaga, C.L. (2003). Targeting the TGF- $\beta$ signalling network in human neoplasia. Cancer Cell 3:531-536.

Fabioux, C., Pouvreau, S., Le Roux, F., and Huvet, A. (2004). The oyster vasa-like gene: a specific marker of the germ-line in Crassostrea gigas. Biochem Biophys Res Commun 315:897-904.

Fabioux, C., Huvet, A., Le Souchu, P., Le Pennec, M., and Pouvreau, S. (2005). Temperature and photoperiod drive Crassostrea gigas reproductive internal clock. Aquaculture 250:458-470.

Fabioux, C., Corporeau, C., Quillien, V., Favrel, P., and Huvet, A. (2009). In vivo RNA interference in oyster-vasa silencing inhibits germ cell development. FEBS Journal 276:25662573.

Fleury, E., Fabioux, C., Lelong, C., Favrel, P., and Huvet, A. (2008). Characterization of a gonad-specific transforming growth factor- $\beta$ superfamily member differentially expressed during the reproductive cycle of the oyster Crassostrea gigas. Gene 410, 187-196.

Fleury, E., Moal, J., Boulo, V., Daniel, J.Y., Mazurais, D., Hénaut, A., Corporeau, C., Boudry, P., Favrel, P., and Huvet A. (2010). Microarray-based identification of gonad transcripts differentially expressed between lines of Pacific oyster selected to be resistant or susceptible to summer mortality. Marine Biotech, 12, 326-339. 
Ge, W. (2005). Intrafollicular paracrine communication in the zebrafish ovary: the state of the art of an emerging model for the study of vertebrate folliculogenesis. Mol Cell Endocrinol 237:1-10.

Gilchrist, R.B., Ritter, L.J., Cranfield, M., Jeffery, L.A., Amato, F., Scott, S.J., Myllymaa, S., Kaivo-Oja, N., Lankinen, H., Mottershead, D.G., Groome, N.P., and Ritvos, O. (2004). Immuno-neutralization of growth differentiation factor 9 reveals it partially accounts for mouse oocyte mitogenic activity. Biol Reprod 71:732-739.

Groisillier,A., Herve, C., Jeudy, A., Rebuffet, E., Pluchon, P.F., Chevolot, Y., Flament, D., Geslin, C., Morgado, I.M., Power, D., Branno, M., Moreau, H., Michel, G., Boyen, C., Czjzek, M. (2010). Marine Express: taking advantage of high throughput cloning and expression strategies for the post-genomic analysis of marine organisms. Microb Cell Fact 9:45-56.

Guex, N., and Peitsch, M.C. (1997). SWISS-MODEL and the Swiss-Pdb Viewer: an environment for comparative protein modelling. Electrophoresis 18:2714-2723.

Hernandez-Pando, R., Orozco-Esteves, H., Maldonado, H.A., Aguilar-Leonn, D., VilchisLanderos, M.M., Mata-Espinoza, D.A., Mendoza, V., and Lopez-Casillas, F. (2006). A combination of a transforming growth factor- $\beta$ antagonist and a inhibitor of cyclooxygenase is an effective treatment for murine pulmonary tuberculosis. Clin Exp Immunol 144:264-272.

Herpin, A., Lelong, C., and Favrel, P. (2004). Transforming growth factor-beta-related proteins: an ancestral and widespread superfamily of cytokines in metazoans. Dev Comp Immunol 28:461-485.

Huvet, A., Normand, J., Fleury, E., Quillien, V., Fabioux, C., Boudry, P. (2010). Reproductive effort of Pacific oysters: a trait associated with susceptibility to summer mortality. Aquaculture 304:95-99.

Ingman, W.V., and Robertson, S.A. (2002). Defining the actions of transforming growth factor- $\beta$ in reproduction. BioEssays 24:904-914.

Itman, C., Mendis, S., Barakat, B., and Loveland, K.L. (2006). All in the family: TGF- $\beta$ family action in testis development. Reproduction 132:233-246.

Josso, N., and Di Clemente, N. (1999). TGF-beta family members and gonadal development. Trends Endocrinol Metab 10:216-222.

Knight, P.G., and Glister, C. (2006). TGF- $\beta$ superfamily members and ovarian follicle development. Reproduction 132:191-206.

Kohli, G., Hu, S., Clelland, E., Di Muccio, T., Rothenstein, J., and Peng, C. (2003). Cloning of transforming growth factor- $\beta 1$ and its type II receptor from zebrafish ovary and role of TGF$\beta 1$ in oocyte maturation. Endocrinology 144(5):1931-1941.

Kohli, G., Clelland, E., and Peng, C. (2005). Potential targets of transforming growth factor$\beta 1$ during inhibition of oocyte maturation in zebrafish. Reprod Biol Endocrinol 3:53-59.

Le Foll, C., Corporeau, C., Le Guen, V., Gouygou, J.P., Bergé, J.P., and Delarue, J. (2007). Long-chain n-3 polyunsaturated fatty acids dissociate phosphorylation of Akt from phosphatidylinoisitol 3'-kinase activity in rats. Am J Physiol Endocrinol Metabol 292: 12231230. 
Lelong, C., Mathieu, M., and Favrel., P. (2000). Structure and expression of mGDF, a new member of the transforming growth factor-beta superfamily in the bivalve mollusc Crassostrea gigas. Eur J Biochem 267:3986-3993.

Lelong, C., Badariotti, F., Le Quere, H., Rodet, F., Dubos, M.P., and Favrel, P. (2007). CgTGF- $\beta$, a TGF- $\beta$ /activin homologue in the Pacific oyster Crassostrea gigas, is involved in immunity against Gram-negative microbial infection. Dev Comp Immunol 31(1):30-38.

Leighton, M., and Kadler, K.E. (2003). Paired basic/furin-like proprotein convertase cleavage of pro-BMP-1 in the Trans-Golgi network. J Biol Chem 278:18478-18484.

Lyon, M., Rushton, G., and Gallagher, J.T. (1997). The interaction of the transforming growth factor-betas with heparin/heparan sulfate is isoform-specific. J Biol Chem 272:18000-18006.

Ma, L.J., Jha, S., Ling, H., Pozzi, A., Ledbetter, S., and Fogo, A.B. (2004). Divergent effects of low versus high dose anti-TGF- $\beta$ antibody in puromycin aminonucleoside nephropathy in rats. Kidney Int 65:106-115.

Massague, J., and Wotton, D. (2000). Transcriptional control by the TGF- $\beta / S m a d$ signalling system. EMBO J 19:1745-1754.

Massague, J., Blain, S.W., and Lo, R.S. (2000). TGF- $\beta$ signalling in growth control, cancer, and heritable disorders. Cell 103:295-309.

Memon, M.A., Anway, M.D., Covert, T.R., Uzumcu, M., and Skinner, M.K. (2008). Transforming growth-factor beta (beta 1 , beta 2 and beta 3) null-mutant phenotypes in embryonic gonadal development. Mol Cell Endocrinol 294:70-80.

Mendez, C., Alcantara, L., escalona, R., Lopez-Casillas, F., and Pedernera, E. (2006). Transforming growth factor beta inhibits proliferation of somatic cells without influencing germ cell number in the chicken embryonic ovary. Cell Tissue Res 325:143-149.

Moore, R.K., Erickson, G.F., and Shimasaki, S. (2004). Are BMP15 and GSDF9 primary determinants of ovulation quota in mammals? Trends Endocrinol Metab 15:356-361.

Moore, R.K., and Shimasaki, S. (2005). Molecular biology and physiological role of the oocyte factor BMP15. Mol Cell Endocrinol 234:67-73

Omer, F.M., and Riley, E.M. (1998). Transforming growth-factor- $\beta$ production is inversely correlated with severity of murine malaria infection. J Exp Med 188:39-48.

Otsuka, F., Yamamoto, S., Erickson, G.F., and Shimasaki, S. (2001). Bone morphogenetic protein-15 inhibits follicle-stimulating hormone (FSH) action by suppressing FSH receptor expression. J Biol Chem 276:11387-11392.

Patterson, G.I., and Padgett, R.W. (2000). TGF- $\beta$ related pathways: roles in Caenorhabditis elegans development. Trends Genet 16:27-33.

Pinheiro, R.O., Pinto, E.F., Lopes, J.R., Guedes, H.L., Fentanes, R.F., and Rossi-Bergmann, B. (2005). TGF-beta associated enhanced susceptibility to leishmaniasis following intramuscular vaccination of mice with leishmania amazonensis antigens. Microbes Infect 7:1317-1323.

Rider, C.C. (2006). Heparin/heparan sulphate binding in the TGF-beta cytokine superfamily. Biochem Soc Trans 34:458-460. 
Royer, J., Seguineau, C., Park, K., Pouvreau, S., Choi, K.S., Costil, K. (2008). Gametogenetic cycle and reproductive effort assessed by two methods in 3 age classes of Pacific oysters, Crassostrea gigas, reared in Normandy. Aquaculture 277:313-320.

Samain, J.F., Dégremont, L., Soletchnik, P., Haure, J., Bédier, E., Ropert, M., Moal, J., Huvet, A., Bacca, H., Van Wormhoudt, A., Delaporte, M., Costil, K., Pouvreau, S., Lambert, C., Boulo, V., Soudant, P., Nicolas, J.L., Le Roux, F., Renault, T., Gagnaire, B., Géret, F., Boutet, I., Burgeot, T., and Boudry, P. (2007). Genetically based resistance to summer mortality in the Pacific oyster Crassostrea gigas and its relationship with physiological, immunological characteristics and infection process. Aquaculture 268:227-243

Samain, J.F., and Mc Combie, H. (2008). Summer mortality of Pacific oyster Crassostrea gigas. The Morest Project. Quae Ed.

Sawatari, E., Shikina, S., Takeuchi, T., and Yoshizaki, G. (2007). A novel transforming growth factor-b superfamily member expressed in gonadal somatic cells enhances primordial germ cell and spermatogonial proliferation in rainbow trout Oncorhynchus mykiss. Dev Biol 301:266-275.

Scheufler, C., Sebald, W., and Hülsmeyer, M. (1999). Crystal structure of human bone morphogenetic protein-2 at 2.7 A resolution. J Mol Biol 287:103-115.

Schulz, R.W., DeFrança, L.R., Lareyre, J.J., LeGac, F., Chiarini-Garcia, H., Nobrega, R.H., and Miura, T. (2009). Spermatogenesis in fish. Gen Comp Endocrinol 165:390-411.

Sharma, K.,, Jin, Y., Guo, J., and Ziyadeh, F.N. (1996). Neutralization of TGF- $\beta$ by anti-TGF$\beta$ antibody attenuates kidney hypertrophy and the enhanced extracellular matrix gene expression in STZ-induced diabetic mice. Diabetes 45:522-530.

Shimasaki, S., Moore, R.K., Otsuka, F., and Erickson, G.F. (2004). The bone morphogenetic protein system in mammalian reproduction. Endocr Rev 25:72-101.

Steele, S., and Mulcahy, M.F. (1999). Gametogenesis of the oyster Crassostrea gigas in southern Ireland. J Mar Biol Assoc UK 70: 673-686.

Subramanian, G., Schwarz, R.E., Higgins, L., McEnroe, G., Chakravarty, S., Dugar, S., Reiss, M. (2004). Targeting endogenous growth factor beta receptor signalling in Smad4deficient human pancreatic carcinoma cells inhibits their invasive phenotype 1. Cancer Res 64:5200-5211.

Ten Dijke, P., Miyazono, K., and Heldin, C.H. (2000). Signaling inputs converge on nuclear effectors in TGF- $\beta$ signaling. Trends Biochem Sci 25:64-70.

Vitt, U.A., Hsu, S.Y., and Hsueh, A.J. (2001). Evolution and classification of cystine knotcontaining hormones and related extracellular signalling molecules. Mol Endocrinol 15:681694.

Zdobnov, E.M., and Apweiler, R. (2001). InterProScan-an integration platform for the signature-recognition methods in InterPro. Bioinformatics 17:847-848. 


\section{Figures}

Figure 1. Schematic representation of og TGF- $\beta$ primary sequence.

(A) Schematic representation of the entire og TGF- primary sequence of 307 amino acids. Signal peptide (aa 1-18), pro-domain (aa 19-186) and carboxy-terminal mature og TGF- $\beta$ (aa 187-307) are shown in black, grey and white, respectively. Partial sequence of the putative pro-domain cleavage site is shown below with the RFKR furin recognition site at $\mathrm{Arg}^{186}$ underlined (B) Schematic representation of recombinant GST-tagged pro-og TGF- $\beta$. corresponding to the protein deleted from its signal peptide and containing a GST-tag. Recognition sites for digestion by thrombin (white arrow) or furin (black arrow) are represented. Calculated molecular weight is indicated for each part of the protein.

(A)

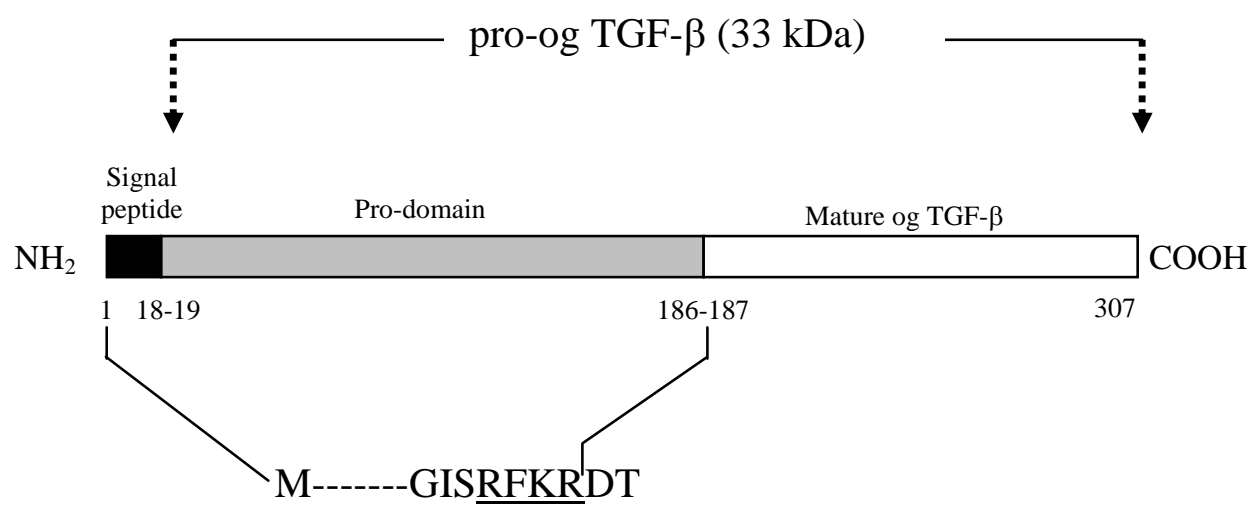

(B)

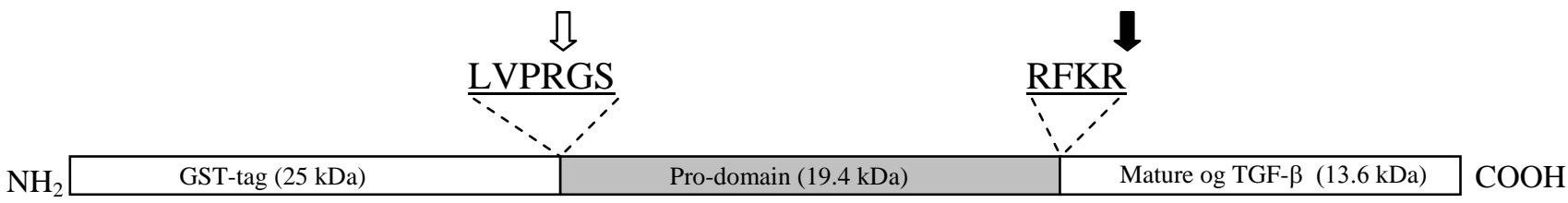

GST-tagged pro-og TGF- $\beta$ (58 kDa) 
Figure 2. Expression of recombinant GST-tagged pro-og TGF- $\beta$

Protein separated on $10 \%$ SDS-PAGE and detected by staining with Coomassie brilliant blue. (A) (M) Molecular weight markers. (1) Protein eluted after bacterial expression-test. (Black arrowhead) Band detected at $58 \mathrm{kDa}$ corresponding to GST-tagged pro-og TGF- $\beta$. (B) Protein extracted from large-scale culture after French press disruption of bacteria. (I) Insoluble proteins contained in the bacteria pellet. (S) Soluble proteins. (Black arrowhead) Band detected at $58 \mathrm{kDa}$ corresponding to GST-tagged pro-og TGF- $\beta$. (C) Representative SDS-PAGE of 3 fractions (1-3) collected by HPLC elution. (Black arrowhead) Band detected at $58 \mathrm{kDa}$ corresponding to GST-tagged pro-og TGF- $\beta$. Sizes of marker proteins are given in the margin.

(A)

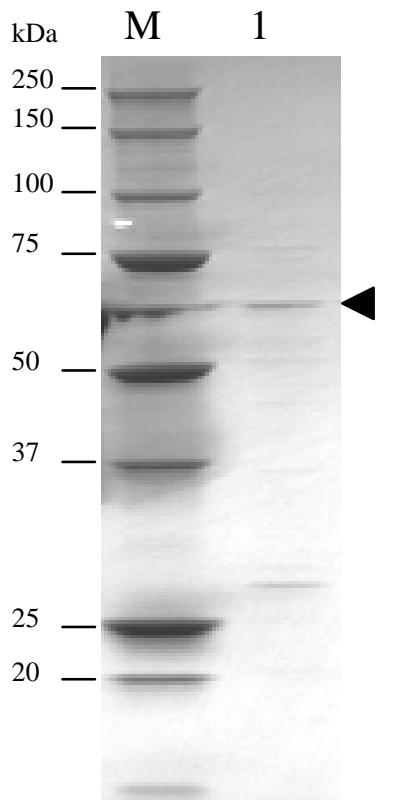

(C)

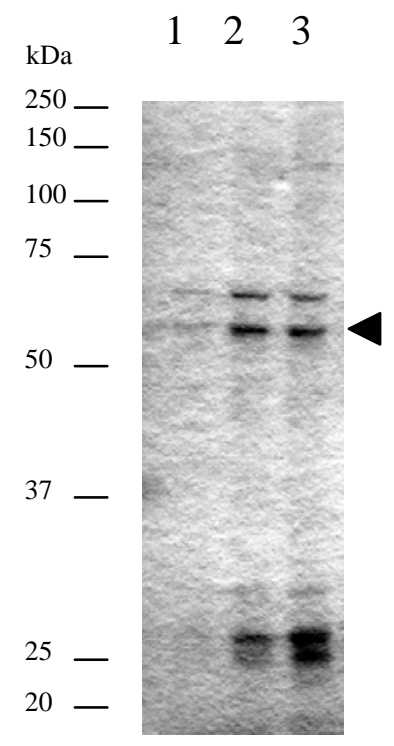

(B)

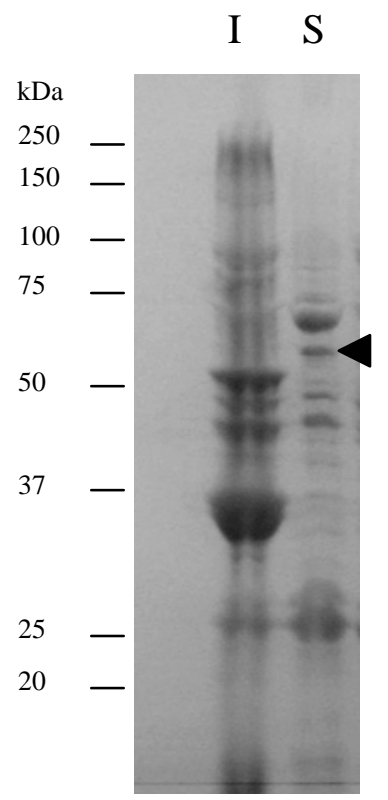


Figure 3. Digestion of recombinant GST-tagged pro-og TGF- $\beta$ by furin or thrombin.

Digest products separated on $10 \%$ SDS-PAGE and detected by staining with Coomassie brilliant blue. (A) Recombinant GST-tagged pro-og TGF- $\beta$ was treated with thrombin (at $20^{\circ} \mathrm{C}$ ) during 1 min (1'), $30 \mathrm{~min}\left(30^{\prime}\right), 1$ hour, 2 hours, 3 hours and 24 hours. (Black arrowhead) Band detected at $58 \mathrm{kDa}$ corresponding to GST-tagged pro-og TGF- $\beta$. (Grey arrowhead) Band detected at $33 \mathrm{kDa}$ corresponding to pro-og TGF-. liberated from GST-tag by thrombin. (White arrowhead) Liberated GST-tag detected at $25 \mathrm{kDa}$. (B) Recombinant GST-tagged pro-og TGF- $\beta$ treated with furin (at $20^{\circ} \mathrm{C}$ or $37^{\circ} \mathrm{C}$ ) during $1 \mathrm{~min}, 5 \mathrm{~min}, 1$ hour, 2 hours, 3 hours and 24 hours. (Black arrowhead) Band detected at $58 \mathrm{kDa}$ corresponding to GST-tagged pro-og TGF- $\beta$. (Grey arrowhead) Band detected at $42.4 \mathrm{kDa}$ corresponding to GST-tagged pro-domain liberated from mature og TGF- by furin. Sizes of marker proteins are given in the left margin.

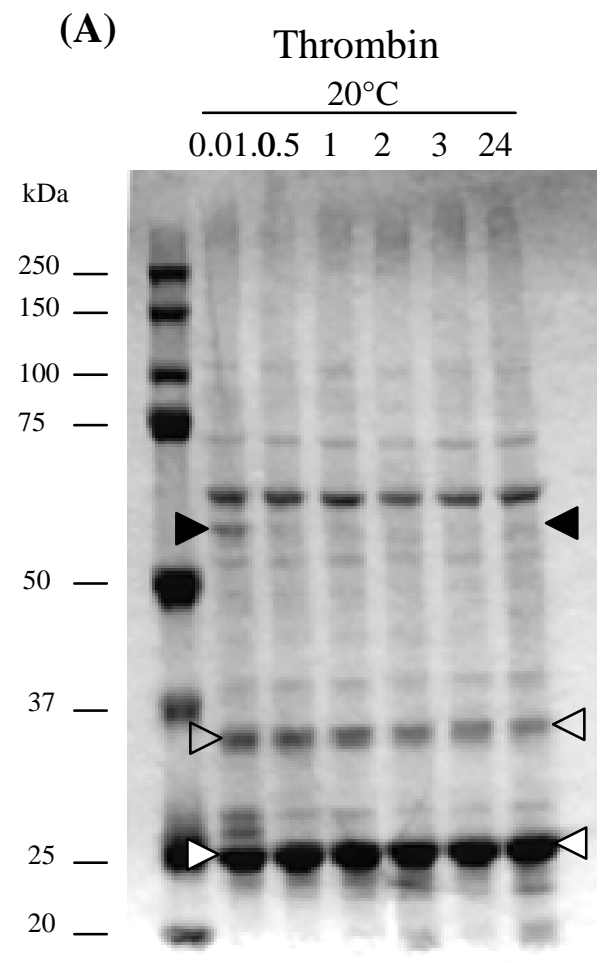

(B)

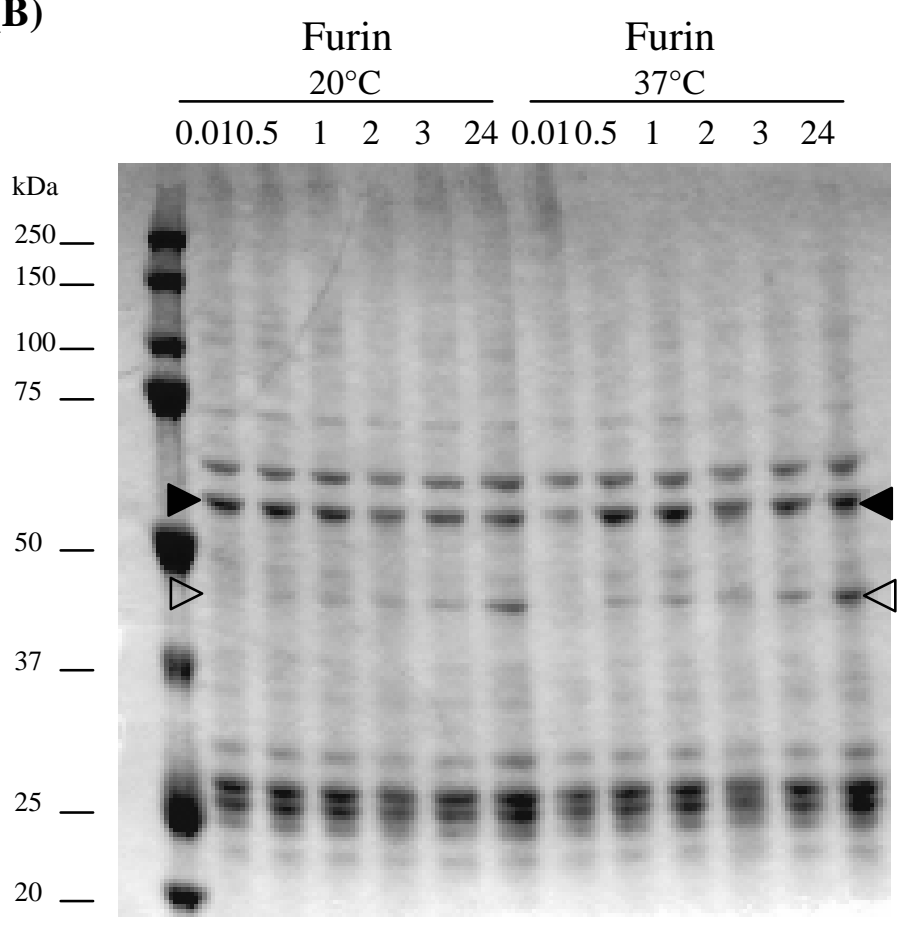


Figure 4. Immunodetection on western-blot using anti-TGF- $\beta$ antibody.

Protein analysed by $15 \%$ SDS-PAGE and immunodetection using heterologous pan-specific anti-TGF- $\beta$ polyclonal antibody. The lower zone of the western-blot revealed by ECL is shown. (R) Recombinant mature og TGF- $\beta$ obtained in furin digestion products. (M) Total protein extracted from male mature gonad. (F) Total protein extracted from female mature gonad. (Black arrowhead) Band of $13.6 \mathrm{kDa}$ corresponding to mature og TGF- $\beta$ recognized by the antibody. Sizes of marker proteins are given in the left margin.

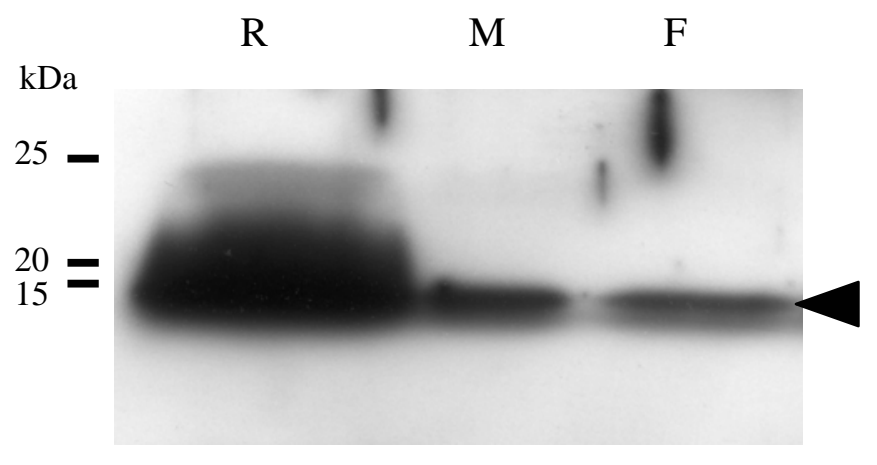

Figure 5. 3D structure modelling

Ribbon diagrams showing the tertiary structure of mature og TGF- $\beta$ (oyster) compared to human BMP-2 (human): $\alpha$-helices are indicated as spirals, $\beta$-strands as arrows. (Asterisk) Secondary $\alpha$-helices structures specific to the BMP sub-group. Modelling was done using the SWISS-MODEL automated protein modelling server.

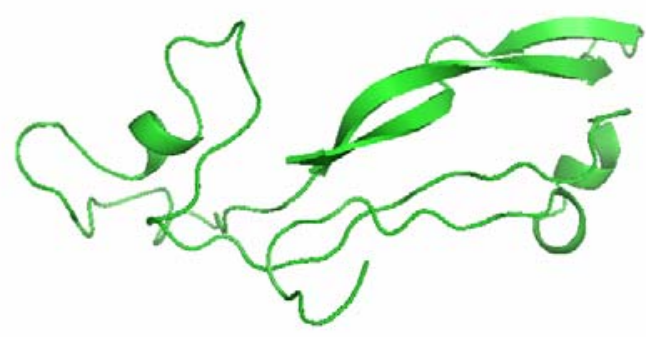

oyster

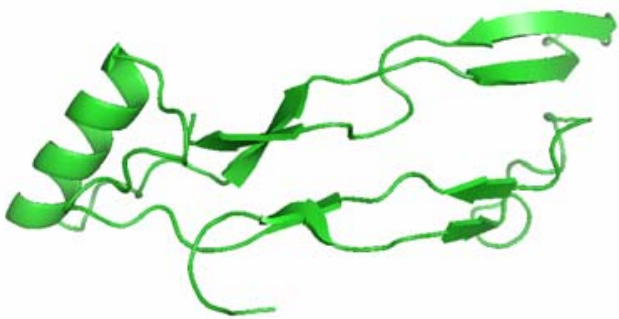

human 
Figure 6. Quantitative histology

Mean reproductive effort estimated by the area occupied by the gonad (in \%) for control oysters injected with PBS (black bar; control) and oysters injected with the pan-specific antiTGF- $\beta$ polyclonal antibody (gray bar; TGFb), $n=10$. Results are expressed as mean $\pm \mathrm{SE}$.

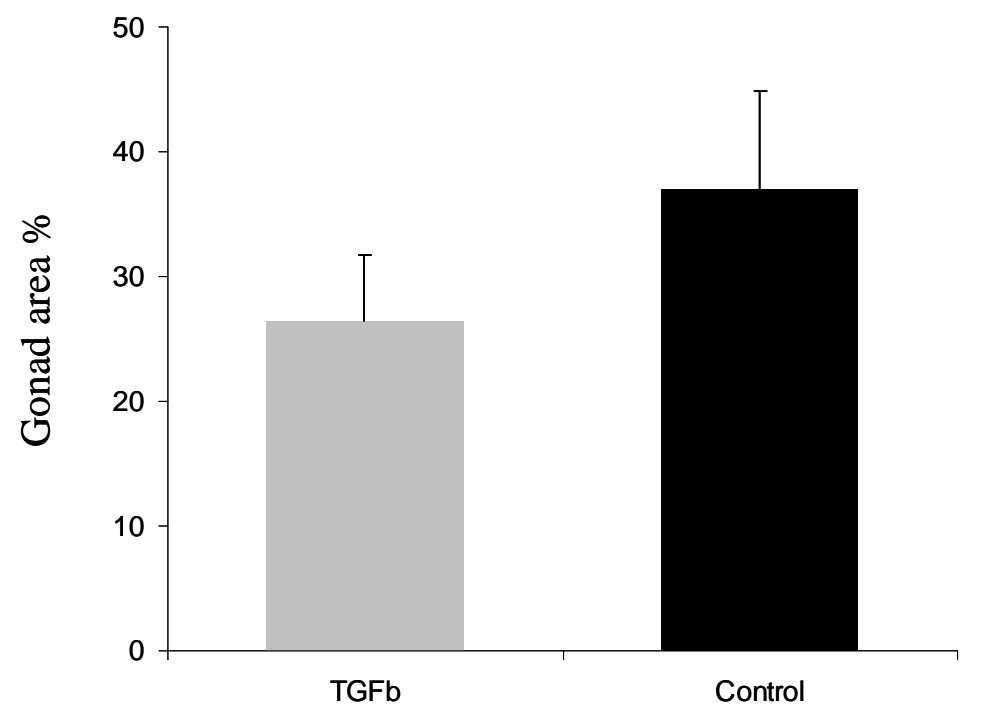

